Борис Норман

Белорусский государственный университет

Филологический факультет

Кафедра теоретического и славянского языкознания

boris.norman@gmail.com
УДК 811.161.1'367

https://doi.org/10.18485/slavistika.2020.24.2.2

оригинални научни рад примљено 05.08.2020.

прихваћено за штампу 18.09.2020.

\title{
ВНУТРЕННИЕ ПРЕОБРАЗОВАНИЯ СТРУКТУРЫ ПРЕДЛОЖЕНИЯ И ТРУДНЫЕ СЛУЧАИ СИНТАКСИЧЕСКОГО РАЗБОРА
}

Синтаксическая структура высказывания рассматривается в плане ее создания - с динамических, психолингвистических позиций. Представленный в статье материал демонстрирует разнообразные черты живой спонтанной речи: хезитацию, самообрыв, трансформацию морфологической характеристики слова, внутреннюю перестройку фразы. Эти явления, составляющие специфику синтаксиса речи (в отличие от синтаксиса языка), требуют пересмотра традиционной для русской грамматики системы членов предложения.

Ключевые слова: синтаксис речи, внутренняя речь, член предложения, высказывание, преобразование синтаксической структуры, компрессия.

The syntactic structure of the utterance is considered in terms of its formation - from dynamic, psycholinguistic positions. The material presented in the article demonstrates various features of spontaneous living speech: hesitation, self-termination, transformation of the morphological characteristics of the word and the internal restructuring of the phrase. These phenomena, which make up the specific qualities of speech syntax (as opposed to language syntax), require a revision of the parts of the sentence system, traditional for Russian grammar.

Keywords: speech syntax, inner speech, parts of the sentence, parsing, utterance, syntactic structure transformation, compression.

\section{1. Формирование высказывания во внутренней речи}

В акте речи участвует несколько составляющих. Во-первых, это некоторый фрагмент объективной действительности: предмет, факт, событие, его образ или мысль о нем. Во-вторых, это языковая система, в каком-то своем виде заложенная в сознании человека (говорящего и слушающего) - так называемая языковая компетенция. В-третьих, должен быть некий стимул, позыв, превращающийся в голове человека в речевую интенцию, желание что-то сказать. Начиная с этой интенции и заканчивая высказыванием «на выходе», мы имеем дело с латентным процессом, который Л.С. Выготский называл внутренней речью (Выготский 1982: 331-361).

Процесс внутренней речи сегодня активно исследуется учеными. К теоретическому обоснованию этой лингвоментальной деятельности (представленному в работах Л.С. Выготского, Ж. Пиаже, А.Р. Лурия и др.) подключаются результаты психофизиологических и нейролингвистических наблюдений и экспериментов, см. например (Ушакова и др. 1989). В центре внимания оказывается формирование будущего высказывания. Принимается, что, опираясь на свой речевой опыт, говорящий выбирает принципиальную схему (модель) высказывания, во взаимодействии с лексикой, которая этой модели соответствует. Эта структур- 
ная основа прорабатывается и «обрастает» деталями, а лексические единицы, выбираемые из тематических объединений-кластеров, увязываются друг с другом по правилам комбинаторики. Последовательность «включения» языковых уровней в речевую деятельность и особенности их взаимодействия составляют предмет не затихающей дискуссии (Лурия 1975: 31-40; Ушакова 1979: 169184; Ахутина 1989: 71-109; Levelt 1989: 9; Норман 1994: 104-121; Levelt 1995; Bordag 2005; Седов 2007: 15-16; Dietrich 2007: 37-54 и др.). Приведем в качестве иллюстрации краткое описание этапов «формирования речи говорящего» в одной из моделей:

«Появление недифференцированной, только в общих чертах ясной схемы содержания, предвосхищение некоторых элементов содержания, поэтапное, но неровное его выяснение, проявляющееся то в постепенном, прогрессивном развертывании его, то в регрессивной доработке и добавочной детализации его. К общей схеме содержания подбираются отдельные схемы выражения, которые в свою очередь реализуются то плавно, без каких-либо неровностей, то с перерывами, внутренним взаимоперекрытием и попутными частными изменениями деталей. В результате речь состоит из сегментов с большой а мпли тудой информативной ценности и с разной степенью автономнос ти построения» (Кожевникова 1970: 32).

Конечно, во внутренней речи еще нет «готовых» слов с их полноценным морфологическим и фонетическим оформлением, это еще некие «словообразы», «пред-слова». И отношения между ними еще не установились, а только устанавливаются. Естественно, это проявляется в случаях хезитации, возвратов, лексических субститутов и т.П. Приведем один пример из реальных записей устной речи:

И вот по каменному ложу течет река // Там ни песка нет / ничего / только камень / как будто вот он вылит вот как-то // И там в камне такие... м... впадины / и в них вода/ и ос... листья / разноцветные/ плавают/ вот так вот (жест) (Земская1978: 90).

Примеры такой «работы» говорящего над высказыванием - подбора слов, колебаний, перестройки, обрыва уже начатого - часто фиксируются в художественной литературе. Однако привлечение этого материала требует оговорки. Появление элементов спонтанной разговорной речи в романе или повести следует трактовать как ее имитацию или стилизацию, а не как аутентичные образцы. В этом смысле ценность художественной литературы как источника материала для исследования процессов внутренней речи относительна. Однако у данной оговорки есть и другая сторона. Поскольку художественный текст обладает семиотической природой, то любая его черта принимает знаковый для читателя характер. И, следовательно, вкрапляя в свой текст те или иные речевые отклонения, специфические особенности, писатель посылает читателю сигнал: это настоящая, реальная, но и ная речь! Обратимся еще раз к книге К. Кожевниковой:

«Художественные эквиваленты спонтанной устной речи представляют одно из средств, при помощи которого можно придавать литературному вымыслу видимость реальности. Следовательно, они фигурируют в художественном 
произведении в качестве одного из элементов "реалистической мотивировки"» (Кожевникова 1970: 91).

Сказанное, на наш взгляд, оправдывает обращение к художественным текстам как к одному из источников изучения процессов, протекающих в сознании говорящего. Особенно характерны эти сигналы спонтанности для прямой речи персонажей:

- По какому это случаю тут? - спрашивает Очумелов, врезываясь в толпу. Почему тут? Это ты зачем палец?.. Кто кричал? (А. Чехов. Хамелеон).

- Я не мог больше! Где вы были? Отчего, - ни на секунду не отрывая от нее глаз, я говорил, как в бреду - быстро, несвязно - может быть, даже только думал. - Тень - за мною... Я умер - из шкафа... Потому что этот ваш.. говорит ножницами: у меня душа... Неизлечимая... (Е. Замятин. Мы).

- Да нет, нет. - Тут уж я совсем стал путаться. - В этом мире есть вещи... есть такие сферы... нельзя же так просто: встать и пойти. Потому что самоограничение, что ли?.. есть такая заповеданность стыда, со времен Ивана Тургенева... и потом - клятва на Воробьевых горах... И после этого встать и сказать: «Ну, ребята...» Как-то оскорбительно... Ведь если у кого щепетильное сердце... (В. Ерофеев. Москва - Петушки).

Естественно, это оборачивается оговорками, описками, т.е. отклонениями от литературной нормы. Они затрагивают и синтаксическую структуру высказывания. Издательские редакторы иногда их не исправляют, потому что понимают: это необходимые свидетельства спонтанного характера речи:

Но кругом говорили: «Счастливая - вы едете!» - «Счастливая - в Киеве пирожные с кремом». И даже просто: «Счастливая... с кремом!» (Тэффи. Житьебытье).

Возмутился Митрофан, серьезно, глубоко:

- Вернусь домой - разобью все ее пластинки! Если артистка живые концерты часто выступает, то не имеет права так себя на экране вести! (В. Конецкий. За доброй надеждой).

ЛАРИСА. ...Кого я тут решила судить? Нет, я буду играть Клеопатру и вхожу в образ. Некому мне судить. Всё. До свидания (Н. Коляда. Куриная слепота).

Многообразные свидетельства перестройки высказывания обнаруживаются и в авторской речи. Они опять-таки либо воспринимаются как проявления креатива, речевого творчества, либо закрепляются, «легализуются» в тексте как сигналы ошибок, речевых сбоев. Начнем наши примеры с эпохи русской классики:

...Я не умел представить себе Пушкина семьянином и царедворцем; женакрасавица и придворная служба пугали меня за него (И. Пущин. Записки о Пушкине).

Как это следует понимать: жена и служба пугали меня за него? Есть основания предполагать, что в сознании автора параллельно возникли две синонимичные конструкции: я опасался (пугался) за него и его жена и служба пугали меня. Их совмещение (контаминация) и породило не вполне правильное высказывание. 
В новейшее время подобные преобразования, закрепленные в тексте, становятся почти нормой - это отражение того влияния, которое разговорная речь оказывает на иные функционально-стилевые разновидности русского языка. Несколько примеров.

...Местный красавец в своем стерильном кабинете выписал ей какие-то мертвому припарки за бешеные деньги, застраховать старушку в свое время никому и в голову не пришло (Л. Петрушевская. Богиня Парка).

И здесь мы вправе восстановить прообраз этой конструкции, существовавший в сознании говорящего: выписал ей за бешенье деньги какие-то средства, которые могли ей помочь, как мертвому припарки.

Хочешь ответ? Я дам его тебе, только подумаю немного. И помогу себе из фляжки ямайского рома. Лучший ром в мире - кубинский, но я не покупаю его никогда... (Б. Кенжеев. Обрезание пасынков).

Понимание выделенной («неправильной») части фразы не вызывает у читателя никаких трудностей, потому что проецируется на: И помогу себе тем, что налью из фляжки ямайского рома.

Примерно на пятнадцатой странице в ванную пришла архиповская собака, вдоволь навалявшаяся на диване (Т. Устинова. Пороки и их поклонники).

Это значит: Когда Архипов читал примерно пятнадцатую странищу книги... или Когда Архипов дошел в своем чтении до пятнадцуатой страницыь, в ванную комнату пришла собака...

Домашние спрашивали, какая из себя эта рекордсменка Гиннеса. А я не помню ни лица, ни фигуры (Слава Сэ. Разводы).

За выражением рекордсменка Гиннеса скрывается сложная синтаксическая конфигурация «женщина, достойная того, чтобы быть включенной в Книгу рекордов Гиннеса». Словообразы «рекорд» и «Гиннес» послужили смысловыми доминантами, позволившими сократить остальную часть высказывания.

Кривоногий местный тракторист с локонами вокзальной шлюхи был окружен назойливыми румяными поклонницами.

- Умираю пива! - вяло говорил он. И девушки бежали за пивом (С. Довлатов. Заповедник).

Умираю пива! - это всё, что осталось «на выходе» от сложной пропозиции, имевшей место во внутренней речи: Я просто умираю (=могу умереть) от того, что очень сильно хочу пива. При всей кажущейся бессвязности реплики тракториста, она приводит к должному перлокутивному эффекту.

Конечно, те случаи «восстановления» исходной смысловой структуры, которые мы здесь предлагаем, носят условный, приблизительный характер. Читатель (или слушающий) не может на 100\% гарантировать себе, что именно такая структура складывалась в голове у говорящего (пишущего). Более того, иногда автор сознательно оставляет читателю широкое поле для домыслов. Примером может послужить следующая цитата:

Маша выбрала ближайший к выходу ботинок. Он полностью ее устроил. От босоножек отказалась, потому что пальцы (Слава Сэ. Последний сантехник). 
Что значит - пальц̧ы? Это может значить: пальц̧ы из них вылезают; ремешок режет пальцьы; она не любит показывать пальц̧ы; на пальц̧ах - облезльй педикюр и т.п.

Как видим, преобразования, имеющие место во внутренней речи, многообразны: они могут включать в себя элиминацию (исключение) каких-то словообразов или их частеречную трансформацию, или перемещение во внутренней структуре фразы (по «горизонтали» и по «вертикали»), что означает перераспределение связей между словами, и т.п.

\section{2. Синтаксис языка и синтаксис речи?}

Все сказанное заставляет лингвистов различать синтаксис языка и синтаксис речи. Синтаксис языка - это совокупность идеальных, стандартных правил построения предложения, закрепленных в школьных, вузовских и академических грамматиках. А синтаксис речи - это совокупность реальных типов построения устных и письменных текстов, отражающая результат тех внутренних процессов, которые протекают в сознании говорящего и слушающего (включающих такие явления, как трансформация, компрессия, парцелляция и т.д.). Синтаксис речи нуждается в специальных описаниях, можно сказать - в отдельных грамматиках (см.: Ванников 1979).

Применить категории синтаксиса языка к явлениям синтаксиса речи непросто. Вот в вузовском учебнике читаем: «Важным элементом грамматической организации предложения является н али ч и е главны х ч ле н о в (Касаткин 2001: 650). И далее: «Подлежащее является определяемым главным членом, сказуемое - определяющим. Для русского языка характерны две основные формы подлежащего - номинативное и инфинитивное. <..> Все разнообразные формы номинативного подлежащего в той или иной степени уподобляются имени существительному в именительном падеже - им свойственны предметное значение и независимая форма» (Там же: 658). Но даже определить, имеется ли в высказывании главный член - подлежащее или сказуемое - не всегда легко. Школьная грамматика прибегает, в соответствии с традицией, к сочетанию смысловых и формальных критериев. В пособии, составленном учеными МГУ для школьников, говорится: «Подлежащее - это главный член двусоставного предложения, который называет то, о чем говорится в предложении» (Литневская 2006: 167). В соответствии с этой дефиницией, мы легко ответим на вопрос, где подлежащее в классическом примере типа Мама мыла раму, но уже по отношению к следующему азбучному образцу - У Шуры шары - могут возникнуть сомнения - о чем тут говорится: о Шуре или о шарах? Поэтому нам дается подсказка: подлежащее в наиболее типичном случае выражается формой именительного падежа существительного. Значит, иары - подлежащее.

В школе при синтаксическом разборе предложения используются условные вопросы: кто делает? Что делает? и т.д. А.М. Пешковский, посвятивший этой методике специальную статью, оценивал вопросы как «один из видов грамматического экспериментирования»: подстановки одних слов на место других. Вместе с тем, он подверг такие вопросы уничижительной критике: «Они оказываются тем пробковым поясом, на котором учитель смело (и даже 
иногда задорно) плавает по поверхности языка, не умея ни плавать, ни тем более нырять в его глубины (что с поясом и невозможно). И это учитель плавания!» (Пешковский 1959а: 33). Действительно, в случаях типа пирожок с мясом (какой пирожок? пирожок с чем?) или явиться на зов (явиться когда? явиться почему? явиться на что?) вопросы оказываются бессильными (см.: Федоров 1972: 50-72).

Между тем, в речевой практике, действительно, встречается множество случаев, представляющих трудность при школьном разборе по членам предложения. Одна из объективных предпосылок этих трудностей - это классификация членов предложения, принятая в русской грамматике. Как известно, эта система унаследована от античной науки. Основы ее в течение длительного времени оставались незыблемыми, хотя и подвергались время от времени критике. В частности, проблему составляла упомянутая привязанность подлежащего к морфологической форме номинатива (вплоть до иронической максимы: «Подлежащее - это только другое название для именительного падежа»). В середине XX века формально-морфологические принципы классификации стали вытесняться семантико-синтаксическим подходом. «Придавая чрезмерно большое значение исключительно формальным, «внешним» признакам, традиционный подход признает подлежащим только имя или именное сочетание в именительном падеже и инфинитив. Отождествление подлежащего с именительным падежом ведет не только к искусственному уменьшению числа моделей предложения в языке, но, прежде всего, предполагает поверхностное и ошибочное понимание синтаксических связей внутри предложения» (GuiraudWeber 1978: 129).

Чтобы привести синтаксический анализ в соответствие с речевой реальностью, т.е. соотнести синтаксис языка с синтаксисом речи, надо, по-видимому, отчетливо признать, что член предложения не привязан строго к одной морфологической форме, а может выражаться различными частями речи в различных формах. В том числе и подлежащее может «стоять в косвенных падежах» - сегодня этот тезис уже не кажется чем-то необычным (Шмелев 1976: 34-38; Золотова 1982: 19-28; Циммерлинг 2012 и др.).

Правда, само понятие члена предложения в таком случае обесценивается, становится условным. В.А. Звегинцев, исходя из безграничного многообразия реальных речевых построений, ставил во главу угла при определении синтаксической единицы не предикативность с двусоставностью, а - выражаемый смысл и соотнесенность с ситуацией: «Вот эти два момента - законченность смысла и привязанность к ситуации - и являются определяющими для предложения. Все же остальное в нем - от языка, т.е. от некоторой упорядочивающей абстрактной системы...» (Звегинцев 1976: 176).

Значит, не следует бояться расхождений между языковыми конструктами и их речевыми реализациями, а наоборот - следует их ожидать. Известный советский германист В.Г. Адмони, проанализировав большой объем фактического материала, пришел к выводу: реальная речь полна грамматических неправильностей. Но мы можем попытаться восстановить исходный образец (модель), от которого отталкивался говорящий и который восстанавливает в своем уме слушающий. Процитируем: «Конечно, в бесчисленных разновидностях своих ре- 
чевых проявлений высказывание может чрезвычайно далеко отойти от исходной структуры предложения. <.. > Но всегда, во всех без исключения случаях, если мы остаемся в пределах человеческого языка, обнаруживаются хотя бы отдаленные связи между любыми формами речевого высказывания и типологией предложения в каждом языке» (Адмони 1994: 44). В ходе восстановления исходной структуры мы опираемся как на «логику реалий», так и на множество других высказываний, выглядящих «более правильно» по сравнению с данным. Скажем, понятно, что сосед напротив - это «сосед, сидящий напротив» или «сосед, живущий напротив». Докторский совет - это «совет по присуждению ученой степени доктора наук», а не «совет докторов». А продукты детского питания - это «продукты, предназначенные для детского питания», а не «то, что получается в результате детского питания».

Не только эволюция самого языка, но и развитие науки приводят к тому, что появляются различные грамматические концепции, по-разному объясняющие структуру языковых единиц и пути их реализации в речи. Не вдаваясь в разнообразие этих моделей, мы выберем здесь две трактовки синтаксической модели, наиболее распространенные в русской грамматике.

\section{3. Предикатно-актантная грамматика vs. традиционная грамматика}

Становится ясно, что традиционная грамматика, с ее «китами» - предикативностью, двусоставностью, противопоставлением главных и второстепенных членов - плохо справляется с многообразием реальных речевых построений. И потому каноническое учение о членах предложения постепенно теснится новой - «предикатно-актантной» или «актантно-ролевой» - грамматикой (Мустайоки 2006: 152-168; Левицкий 2011: 227 и др.). Согласно этой концепции, основы которой были заложены французским лингвистом Л. Теньером (Теньер 1988: 2239), предикат, т.е. сказуемое (как правило, глагольное), концентрирует в себе обобщенное представление об отражаемой ситуации, и он же распределяет «роли» между ее участниками (актантами). Скажем, личный глагол написать требует «первого актанта» в именительном падеже (Я написал письмо), причастие написан подразумевает участника в творительном падеже (Мною написано письмо), безличное сказуемое прийтись - зависимого имени в дательном падеже (Мне пришлось написать письмо), а предикат угораздить - имени в винительном падеже (Меня угораздило написать письмо) и т.д. А болезненные точки традиционного синтаксиса - дополнение или обстоятельство? определение или дополнение? и т.п. - снимаются введением последовательности актантов, пронумерованных в соответствии с их важностью/обязательностью для предиката: «первый актант», «второй актант», «третий актант»...

Эти положения чрезвычайно важны и плодотворны для синтаксического разбора предложений, возникших как результат преобразований в грамматике говорящего. В значительной степени проблемы здесь сводятся к борьбе между «морфологизованным» и «неморфологизованным» пониманием членов предложения, которая обостряется в тех случаях, когда высказывание представляет собой результат «переделок», произошедших во внутренней речи говорящего. Несомненное достоинство предикатно-актантной концепции - это особая текстообразующая, или организующая, роль глагола. Другое ее достоинство - вве- 
дение в научный обиход понятия синтаксической (или функционально-синтаксической) позиции, подготовленного трудами Т.П. Ломтева и Г.А. Золотовой. «Ни член предложения, ни словосочетание не являются элементарными синтаксическими единицами», - категорично утверждал Т.П. Ломтев (Ломтев 1958: 38). Эту роль он отводил «позиционному звену в позиционной структуре предложения», или, для краткости, синтаксической позиции (Там же: 47). Синтаксическая позиция не связана прямо с каким-то одним морфологическим выражением, она всецело определяется своей функцией, т.е. «назначением в акте мысли».

Вузовская, а особенно школьная, практика медленно осваивает новые идеи. Тем не менее, грамматический анализ требует «разведения» морфологии и синтаксиса. Осуществить разбор по членам предложения - значит соотнести смысловую функцию словоформы в составе высказывания с ее планом выражения, прежде всего - с морфологической формой. И далеко не всегда это соотношение двух сторон речевой единицы будет соответствовать привычному языковому стандарту. Но здесь открывается возможность и для учителя, и для ученика погрузиться в мир речемыслительных механизмов и понять, каким образом язык «осваивает» действительность.

\section{4. Анализ фактического материала}

Рассмотрим еще несколько примеров из русской художественной литературы. При этом мы попытаемся в каждом случае, с одной стороны, реконструировать речевую тактику говорящего, а, с другой стороны, взглянуть на окончательную структуру с позиций традиционной теории членов предложения. Сначала рассмотрим примеры с речевым «аналогом» подлежащего.

Он с изумительной настойчивостью это повторял, и к нему постепенно привыкли, как к говорящему попугаю. Пьяные не обращали внимания, а потрезвей иногда откликались: «Добрый вечер, дедуля; конечно» (М. Веллер. Огнестрельное).

Здесь потрезвей - это, конечно, «те, кто потрезвей». С точки зрения традиционной грамматики, перед нами - неполное предложение, в котором можно восстановить отсутствующую часть: те, кто или люди, которые и т.П. Но если мы априори принимаем, что выражение подлежащего не ограничивается формой именительного падежа существительного, то ничто нам не мешает принять и более простое решение: потрезвей - это подлежащее! С позиций синтаксиса речи это приемлемый вариант.

В очках внимательно выслушал потерпевшего и продолжал: - Так вот... (А. Арканов. Брюки из лавсана).

В очках, в значении «человек в очках», - это, конечно, подлежащее, другую синтаксическую роль ему приписать невозможно. Кто выслушал? - в очках.

Разумеется, произошедшие во внутренней речи преобразования синтаксической структуры затрагивают не только главные, но и второстепенные члены предложения. Так, в следующих предложениях мы наблюдаем сдвиги в статусе словоформ, изначально предназначенных для позиций обстоятельств и дополнений. 
Когда пыль унеслась, кентурион крикнул:

- Молчать на втором столбе! (М. Булгаков. Мастер и Маргарита).

На втором столбе тут - не обстоятельство места, как можно было бы подумать в отрыве от данного контекста, а дополнение: молчать кому? - на втором столбе! Неопределенная форма глагола, обозначающая приказание, требует зависимого имени в дательном падеже (молчать тому, кто...). Но за неимением такового, функцию адресата сообщения приходится принять на себя «бывшему» обстоятельству места.

- В машине, - сказал я в телефон. - Чем это вы стреляете? Капитана чуть не убили.

- Что-нибудь вылетело? - спросили из машины.

- Да (В. Конецкий. Морские сны).

В машине здесь - это обращение к механикам, которые находятся в машинном отделении судна. Фактически это «вы, которые в машине». Но такое восстановление реплики до «полного» варианта кажется искусственным и ненужным. $B$ машине - столь же естественное и уместное обращение, как какое-нибудь механики или ребята. Обращение, как известно, стоит вне структуры предложения и образует самостоятельную синтаксическую единицу.

Поглядишь, как Антон Степаныч деликатесы разные выбирает и высшей маркой запивает, так вот и думается... (И. Шмелев. Человек из ресторана).

Если для глагола выбирать реализованы обе обязательные валентности (кто выбирает и что выбирает), то у глагола запивать со второй связью некоторая проблема. Ему подчиняется словоформа в творительном падеже: запивает чем? - (высшей) маркой. Понятно, что это - то, что осталось в результате стяжения конструкции вином высшей марки, в которой высшей марки было несогласованным определением к слову вино. Но это вино мы только подразумеваем, а словоформа высшей марки/маркой в результате перестройки синтаксической структуры приняло на себя функции своего «хозяина» (приняв и новое окончание) и стало дополнением. Если подходить к приведенному примеру как к безусловной данности, то, в терминах синхронической грамматики, маркой-косвенное дополнение в творительном падеже.

В моем возрасте свойственно влюбляться в артистов (В. Токарева. Самый счастливый день).

Сказуемому свойственно в норме должны подчиняться две словоформы: кому свойственно и что свойственно (например: девочкам свойственно влюбляться... и т.п.). Но в данном случае позиция «первого участника» ситуации неожиданно занимается обстоятельством времени. Конечно, можно было бы сказать, что в моем возрасте - это и есть обстоятельство времени, а первая «валентность» сказуемого свойственно ничем не занята, не реализована («всем», «людям» и т.п.). Но что значит в моем возрасте? Это и значит «нам, девочкам»!

В последнее время старалась не попадаться ей на глаза. Мне дали народную СССР, а у нее отняли всё - Таирова, театр, жизнь (Ф. Раневская. «Судьба- шлюха»). 
Народная СССР - это речевой остаток от номенклатурного названия «почетное звание народного артиста СССР», в котором словоформы народный и СССР играли роль определений. В результате преобразований, которые произошли во внутренней речи, часть этой составной номинации просто исчезла, пропала, а словоформы народная и СССР поднялись в синтаксической структуре фразы и стали дополнениями. Симптоматично, кстати, что прилагательное народныцй изменило при этом и свой род!

Первое и общее основание, которое можно увидеть во всех приведенных примерах, - это тенденция к экономии речевых усилий. Стремление к «уплотнению» фразы, к сведению нескольких пропозиций в одну речевую единицу (часто соответствующую «простому предложению», согласно общепринятой классификации) вполне объяснимо. Однако тенденция к экономии в синтаксисе не только порождает «неправильные» высказывания, но и требует обновления синтаксической теории. Судя по всему, эта теория будет развиваться в направлении «семантического синтаксиса», и тогда нас ждут новые открытия. Попробуем показать это на следующем примере.

Березовский наставил на него палец.

- Руки вверх, а то буду стрелять! (Е. Парнов. Третий глаз Шивы).

Определение синтаксической роли слов в составе устойчивых (клишированных) выражений составляет особую трудность. Дело в том, что отдельный элемент этих словосочетаний утрачивает свою синтаксическую самостоятельность. Оборот существует уже целиком и применяется почти автоматически в стандартной языковой ситуации. Примером и служит приказание Руки вверx! в составе приведенной цитаты. Понятно, что словоформа руки - это дополнение в винительном падеже. А вверх - это обстоятельство места (куда?). Это возможный ответ, но опять-таки несколько поверхностный. Выражению Руки вверх! в языковом сознании, очевидно, предшествовала более развернутая конструкция: Подними(те) руки вверх! Затем она сократилась, но наречие вверх осталось как представитель группы сказуемого. И фактически это слово в данном выражении и означает «поднимите». Так что если не ограничивать роль сказуемого глагольными формами, то не будет ошибочным считать слово вверх здесь сказуемым.

Для нас, напомним, уже привычно признание роли сказуемого за междометиями со значением однократного действия, типа хлоn, баџ, цุan. В следующей цитате такие слова употреблены в детской речи:

- Я тоже однажды медведя встретил., это было зимой. Пошел я в лес. Гляжу - медведь. Я бах из ружья. А медведь брык на землю (Н. Носов. Три охотника).

Но, возможно, стоит при синтаксическом разборе предложений сделать следующий шаг: с учетом процессов, протекающих в ходе речевой деятельности, считать сказуемыми и словоформы типа прочь, долой, вверх, врозь (когда они концентрируют в себе семантику предиката), а также падежные (или предложнопадежные) и наречные формы в конструкциях типа Техника-молодежи, Судью на мыло! Подарок в студию, Отправление завтра и т.п.? Это - непростое решение, идущее вразрез с традицией, но укладывающееся в теорию семантического синтаксиса и находящее себе подтверждение в постулатах синтаксиса речи. 
Во всяком случае, нет сомнения, что высказывание, пока оно еще не вышло «наружу», а находится на этапе внутренней речи, - это динамическая, изменчивая структура, и ее элементы - лексические и грамматические значения - еще только «ищут» друг друга. Весь «отрицательный языковой материал» (выражение Л.В. Щербы) - ценнейший объект для исследования закономерностей внутренней речи и познания собственной природы языка. Об этом хорошо сказал другой, уже упомянутый нами классик русского языкознания: «Совершенно случайные обмолвки открывают иной раз глубокие просветы в области физиологии и психологии речи» (Пешковский 1959б: 52). А то, что эти явления плохо укладываются в канон нормативной (в том числе и школьной) грамматики, не должно отвращать от их изучения. Механизмы многообразной семантико-синтаксической перестройки, воплощающиеся в конечном счете в эксплицитные морфологические формы, вскрывают для нас истинную сущность языка.

\section{5. Заключение}

Объектом описательной грамматики являются все факты речи, в том числе и те, которые не укладываются в синтаксический «канон». Но структура высказывания может рассматриваться не только как застывшее данное, но и как динамическое образование - с точки зрения порождения и восприятия текста. Такой динамический аспект в рамках дескриптивного подхода, естественный для психолингвистики и синтаксиса речи, позволяет объяснить многие отклонения от языковой нормы и включить их в поле зрения языковеда.

\section{Использованная литература}

Адмони, Владимир Г. Система форм речевого высказывания. Санкт-Петербург: Наука, 1994.

[Admoni, Vladimir G. Sistema form rechevogo vyskazyvaniiā. Sankt-Peterburg: Nauka, 1994]

Ахутина, Татьяна В. Порождение речи. Нейролингвистический анализ синтаксиса. Москва: Издательство Московского университета, 1989.

[Akhutina, Tat'iâna V. Porozhdenie rechi. Neĭrolingvisticheskiı̌ analiz sintaksisa. Moskva: Izdatel'stvo Moskovskogo universiteta, 1989]

Ванников, Юрий В. Синтаксис речи и синтаксические особенности русской речи. Москва: Русский язык, 1979.

[Vannikov, IUriı̌ V. Sintaksis rechi i sintaksicheskie osobennosti russkoî rechi. Moskva: Russkiı̌ iāzyk, 1979]

Выготский, Лев С. Мышление и речь. [В:] Л.С. Выготский. Собрание сочинений. Том 2. Проблемы общей психологии. Москва: Педагогика, 1982, 5-361.

[Vygotskiŭ, Lev S. Myshlenie i rech'. [V:] L.S. Vygotskiĭ. Sobranie sochineniı̌. Tom 2. Problemy obshcheǐ psikhologii. Moskva: Pedagogika, 1982, 5-361]

Звегинцев, Владимир А. Предложение и его отношение к языку и речи. Москва: Издательство Московского университета, 1976.

[Zvegintsev, Vladimir A. Predlozhenie i ego otnoshenie k iāzyku i rechi. Moskva: Izdatel'stvo Moskovskogo universiteta, 1976] 
Земская, Елена А. (ред.). Русская разговорная речь. Тексты. Москва: Наука, 1978. [Zemskaâ, Elena A. (red.). Russkaâ razgovornaâ reč'. Teksty. Moskva: Nauka, 1978]

Золотова, Галина А. Коммуникативные аспекты русского синтаксиса. Москва: Наука, 1982.

[Zolotova, Galina A. Kommunikativnye aspekty russkogo sintaksisa. Moskva: Nauka, 1982]

Касаткин, Леонид Л. (ред.) Русский язык. Москва: Академия, 2001.

[Kasatkin, Leonid L. (red.) Russkiı̌ iâzyk. Moskva: Akademiiā, 2001]

Кожевникова, Квета. Спонтанная устная речь в эпической прозе (на материале современной русской художественной литературы). Praha: Universita Karlova, 1970.

[Koževnikova, Kveta. Spontannaâ ustnaâ reč́ v èpičeskoj proze (na materiale sovremennoj russkoj hudožestvennoj literatury). Praha: Universita Karlova, 1970]

Левицкий, Юрий А. Наши грамматики. [В:] А.Л. Лебедева и др. (ред.) Грамматика разноструктурных языков. Сборник статей к юбилею В.Ю. Копрова. Воронеж: НАУКА-ЮНИПРЕСС, 2011, 222-228.

[Levitskiı̌, IOrǐ̌ A. Nashi grammatiki. [V:] A.L. Lebedeva i dr. (red.) Grammatika raznostrukturnykh iâzykov. Sbornik stateĭ k iübileiû V.IU. Koprova. Voronezh: NAUKAIONIPRESS, 2011, 222-228]

Литневская, Елена И. Русский язык. Краткий теоретический курс для школьников. Москва: Издательство Московского университета; Издательство ЧеРо, 2006.

[Litnevskaiā, Elena I. Russkiı̌ iāzyk. Kratkiı̌ teoreticheskiı̌ kurs dliā shkol'nikov. Moskva: Izdatel'stvo Moskovskogo universiteta; Izdatel'stvo CHeRo, 2006]

Ломтев, Тимофей П. Основы синтаксиса современного русского языка. Москва: Учпедгиз, 1958.

[Lomtev, Timofej P. Osnovy sintaksisa sovremennogo russkogo âzyka. Moskva: Učpedgiz, 1958]

Лурия, Александр Р. Основные проблемы нейролингвистики. Москва: Издательство Московского университета, 1975.

[Luriiā, Aleksandr R. Osnovnye problemy neĭrolingvistiki. Moskva: Izdatel'stvo Moskovskogo universiteta, 1975]

Мустайоки, Арто. Теория функционального синтаксиса: От семантических структур к языковым средствам. Москва: Языки славянской культуры, 2006.

[Mustaîoki, Arto. Teoriiā funktşional'nogo sintaksisa: Ot semanticheskikh struktur k iâzykovym sredstvam. Moskva: IAłzyki slaviânskoĭ kul'tury, 2006]

Норман, Борис Ю. Грамматика говорящего. Санкт-Петербург: Издательство Санкт-Петербургского университета, 1994.

[Norman, Boris ID. Grammatika govoriāshchego. Sankt-Peterburg: Izdatel'stvo Sankt-Peterburgskogo universiteta, 1994]

Пешковский, Александр М. Вопрос о «вопросах». [В:] А.М. Пешковский. Избранные труды. Москва: Учпедгиз, 1959а, 33-49.

[Peshkovskiı̌, Aleksandr M. Vopros o «voprosakh». [V:] A.M. Peshkovskiı̌. Izbrannye trudy. Moskva: Uchpedgiz, 1959a, 33-49]

Пешковский, Александр М. Объективная и нормативная точка зрения на язык. [B:] А.М. Пешковский. Избранные труды. Москва: Учпедгиз, 1959б, 50-62.

[Peshkovskiı̌, Aleksandr M. Ob"ektivnaiā i normativnaiâ tochka zreniiâ na iâzyk. [V:] A.M. Peshkovski1. Izbrannye trudy. Moskva: Uchpedgiz, 1959b, 50-62]

Седов, Константин Ф. К основаниям лингвистики индивидуальных различий 
(о принципах речевого портретирования). [В:] М.А. Кормилицына и др. (ред.) Проблемы речевой коммуникации. Выпуск 7. Саратов, 2007, 6-29.

[Sedov, Konstantin F. K osnovaniiâm lingvistiki individual'nykh razlichǐ̌ (o printsipakh rechevogo portretirovaniia). [V:] M.A. Kormilitšna i dr. (red.) Problemy rechevoĭ kommunikatșii. Vypusk 7. Saratov, 2007, 6-29]

Теньер, Люсьен. Основы структурного синтаксиса. Москва: Прогресс, 1988.

[Ten'er, Liưs'en. Osnovy strukturnogo sintaksisa. Moskva: Progress, 1988]

Ушакова, Татьяна Н. Функциональные структуры второй сигнальной системы. Психофизиологические механизмы внутренней речи. Москва: Наука, 1979.

[Ushakova, Tat'iâna N. Funktsional'nye struktury vtoroř signal'noĭ sistemy. Psikhofiziologicheskie mekhanizmy vnutrenneĭ rechi. Moskva: Nauka, 1979]

Ушакова, Татьяна Н., Павлова, Наталья Д., Зачесова, Ирина А. Речь человека в общении. Москва: Наука, 1989.

[Ušakova, Tat'âna N., Pavlova, Natal'â D., Začesova, Irina A. Reč' čeloveka v obŝenii. Moskva: Nauka, 1989]

Федоров, Александр К. Трудные вопросы синтаксиса. Москва: Просвещение, 1972.

[Fedorov, Aleksandr K. Trudnye voprosy sintaksisa. Moskva: Prosveshchenie, 1972]

Циммерлинг, Антон В. Неканонические подлежащие в русском языке. [В:] М.Д. Воейкова (ред.) От значения к форме, от формы к значению. Сборник статей в честь 80-летия А.В. Бондарко. Москва: Языки славянских культур, 2012, 568-590.

[TSimmerling, Anton V. Nekanonicheskie podlezhashchie v russkom iâzyke. [V:] M.D. Voeǐkova (red.) Ot znacheniiā k forme, ot formy k znacheniiû. Sbornik stateǐ v chest' 80-letiiāA.V. Bondarko. Moskva: IĀzyki slaviānskikh kul'tur, 2012, 568-590]

Шмелев, Дмитрий Н. Синтаксическая членимость высказывания в современном русском языке. Москва: Наука, 1976.

[SHmelev, Dmitriı̌ N. Sintaksicheskaiâ chlenimost' vyskazyvaniiā v sovremennom russkom iâzyke. Moskva: Nauka, 1976]

Bordag, Denisa. "Modely řečové produkce v současné psycholingvistice”. Slovo a slovesnost 66, 2005, 180-193.

Dietrich, Rainer. Psycholinguistik. 2. Auflage. Weimar, 2007.

Guiraud-Weber, Marguerite. Классификация простого предложения и ее последствия для типологии языков. Revue des études slaves. Communications de la Délégation Française au VIII ${ }^{e}$ Congrès International des Slavistes. Zagreb (3-9 septembre 1978). Paris. LI /1-2, 129-137.

Levelt, Wilem J. M. Speaking: From Intention to Articulation. Cambridge: MIT Press, 1989.

Levelt, Wilem J. M. "The ability to speak: from intentions to spoken words". European Review 3 (1), 1995, 13-23. 


\section{Борис Норман}

\section{УНУТРАШЊА ТРАНСФОРМАЦИЈА СТРУКТУРЕ РЕЧЕНИЦЕ И ТЕШКИ СЛУЧАЈЕВИ СИНТАКСИЧКЕ АНАЛИЗЕ}

\section{Резиме}

У раду се проучава синтаксичка структура исказа у смислу њеног стварања - с динамичке, психолингвистичке тачке гледишта. У центру пажње је процес формирања исказа, који се назива, у складу с терминологијом Л. С. Виготског, унутрашњи говор. Материјал који је представљен у раду показује разноликост особина живог, спонтаног говора: оклевање, самопрекидање, трансформацију морфолошких особина речи, реорганизацију фразе. Све ово - природне особине унутрашњег говора - актуелно је до оног тренутка док исказ не добије готов и експлицитан облик. Слушалац (или читалац) мора да реконструише у глави полазну пропозицијску структуру, која је била подвргнута трансформацији. Овакве трансформације чине специфичност синтаксе говора (за разлику од синтаксе језика). Трансформације које се одвијају у унутрашњем говору, и које се испољавају у текстовима у виду одступања, грешака, неправилности, представљају тешкоћу за школску и академску анализу. Оно захтева ревизију традиционалног система реченичних чланова у руском језику и, делимично, одрицање од стандардних морфолошких показатеља. У раду се наводе примери из руске књижевности, праћени интерпретацијом, лингвистичким коментаром, који потврђују оправданост издвајања синтаксе говора у посебан предмет лингвистике.

Кљичне речи: синтакса говора, унутрашњи говор, реченични члан, исказ, трансформација синтаксичке структуре, компресија. 